IRA-International Journal of Management \& Social Sciences

ISSN 2455-2267; Vol.03, Issue 03 (2016)

Institute of Research Advances

http://research-advances.org/index.php/RAJMSS

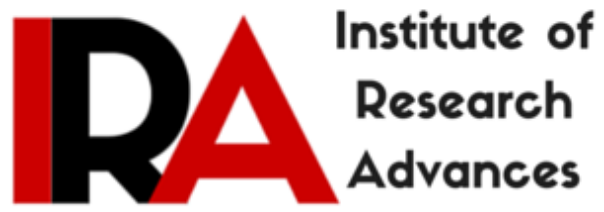

\title{
Discernment of Consumers toward e-shopping: An Indian Perspective Study
}

\author{
Swatantra Kumar, \\ Research Scholar, \\ Department of Business Administration, \\ DDU Gorakhpur University, Pin-273009, India. \\ Dr Sanjay Baijal, \\ Professor, \\ Department of Commerce \& Business, \\ DDU Gorakhpur University, Uttar Pradesh, India.
}

DOI: http://dx.doi.org/10.21013/jmss.v3.n3.p20

\section{How to cite this paper:}

Kumar, S., \& Baijal, D. (2016). Discernment of Consumers toward e-shopping: An Indian Perspective Study. IRA-International Journal of Management \& Social Sciences (ISSN 2455-2267), 3(3). doi:http://dx.doi.org/10.21013/jmss.v3.n3.p20

(C) Institute of Research Advances

\section{(cc) EY-No}

This works is licensed under a Creative Commons Attribution-Non Commercial 4.0 International License subject to proper citation to the publication source of the work.

Disclaimer: The scholarly papers as reviewed and published by the Institute of Research Advances (IRA) are the views and opinions of their respective authors and are not the views or opinions of the IRA. The IRA disclaims of any harm or loss caused due to the published content to any party. 


\section{ABSTRACT}

Purpose: This exploratory study is an attempt to analyse the shift from traditional brick and mortar framework to virtual shopping. The paper further explores the factors which the customers keep into their mind while shopping via online mode.

Design/Methodology: A convenient sampling method has been used to collect data. Questionnaires have been filled through face to face interaction with the respondent of Gorakhpur dist. For this purpose a target of 120 people was set, but many respondents did not give complete information so only 105 surveyed questionnaires were considered for data analysis and interpretation.

Findings: Finding indicate that changing trend \& preference of shopping are significantly related to their age, gender, education, income, familiarity \& past experience. The major deterring factors were found as security measures and lack of physical presence. The result shows that educated, mid-level income earning and web familiar males can provide a target market for e-tailers.

Managerial/practical Implications: Although trend \& preferences of customer are changeable in nature but a continuous look is required to understand the online market. The research may assist e-tailers while formulating, managing and improving their online marketing practices to cater to changing needs of consumers and thereby growing their market share.

Limitations: The study was performed in Gorakhpur city of Uttar Pradesh, India. The result may vary, if the same study accomplished in other region of the country. Time and financial constrains limits the study to pick limited size of sample.

Keywords: Online shopping, e-commerce, Consumer behaviour, Retail trend, shopping intention

\section{PROLOGUE}

With the arrival of Globalisation and liberal economic policy, India has been catching importance as a high potential lucrative market for global retailers companies. MNC's are taking much interest in offering large range of goods \& services to fulfil the need of every segment of the market and want to satisfy almost every customer of the whole India. Shopping trend of people too was not left out of such revolution. It is also undergone a type of digital revolution, showing a clear shift in consumer's attitude and purchase behaviour for different product and services.

A remarkable transformation has been seen in the process and procedures of the business in past five years with the growth of information and communication technology. Now the companies are exploiting their sales and marketing tactics to sell their product and services all through the net. And the customers are experiencing the internet for commercial transactions and facilities like many alternative options, convenience, anytime- anywhere shopping, attractive customized up to date informative portal, cheap and best deals, online reviews, comparative analysis of attributes and prices of different available online products and services and many more. Such transformation is the result of the various factors like increase in education, internet knowledge, income level, changing lifestyle and overall spread of 'consumerism' factor. 
Despite the penetration of such revolutionized trend, it has been seen that there are still many customers who are stick to the traditional pattern of shopping and unwilling to adopt the new trends. However, all is not doom and gloom, it has been reflected in a recent report of e-marketer research firm saying Retail ecommerce sales reached $\$ 5.30$ billion in India in 2014, And this year, retail ecommerce sales, including all products ordered over the internet except travel, will grow $45.2 \%$ to $\$ 7.69$ billion. By the end of 2018 , it is expected to touch $\$ 17.52$ billion. Another report by consulting firm Technopak estimates the e-tailing market to reach $\$ 32$ billion by 2020. Focusing on this emerging picture, market players are framing different types of aggressive marketing strategies and competing with each other in order to capture major portion of the online sales.

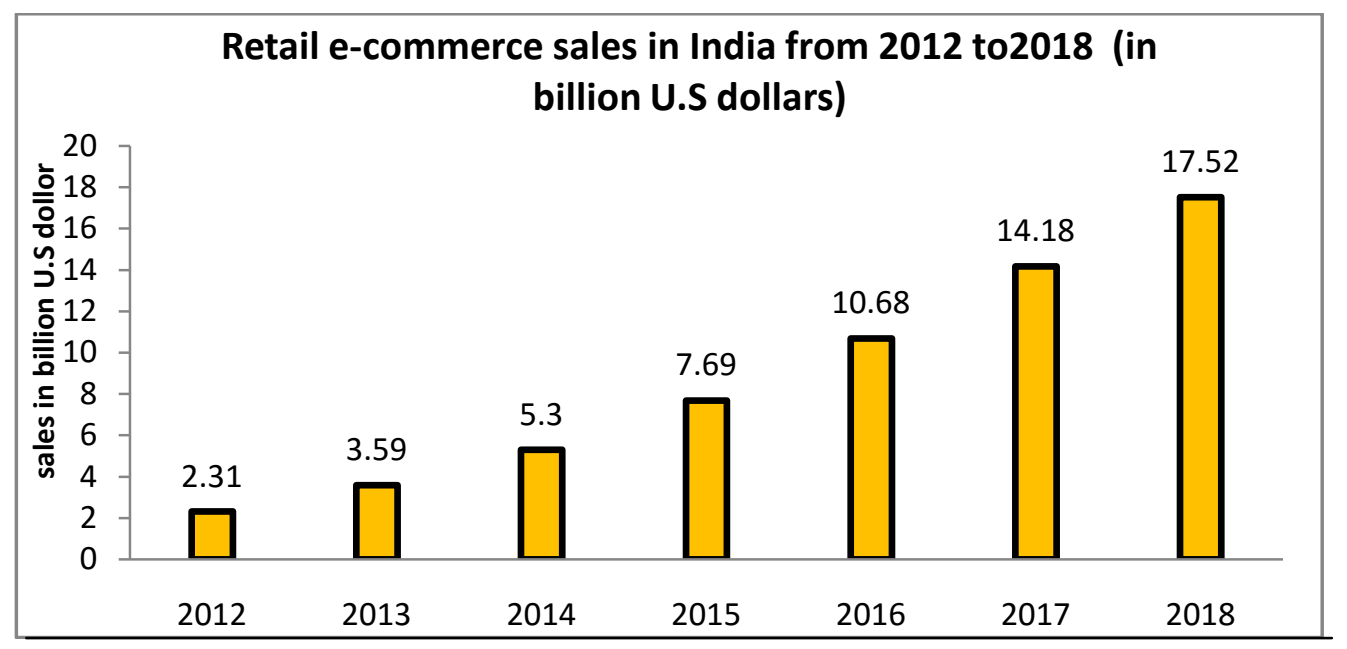

Source : eMarketer 2015

Nowdays e-Retailers offer categories like stationery, books, apparels, electronics, furniture, grocery, personal care, flowers, sports goods and services also. The major players in book category include Amazon, Flipkart, Naaptol and Land mark. Stationery items are sold by online players like Flipkart, Amazon, Stationery shop, Snapdeal and Homeshop 18 etc. In Electronics segment we have specialised players like Croma (Tata group) and E-zone (Future group) alone with other players like Flipkart, amazon, Snapdeal, Infibeam, Naaptol, Future bazar, who sell electronics items like mobile phones, computers, tablets, television and other durables. In Furniture category we have performers like Pepper fry, Fabfurnish, Urban ladder, Zansaar, Home town, and Homeshop18 etc. In jewellery section Carat lane, Juvalia and you are growing well. For baby product we have First cry, my baby cart website. In Apparel and personal care segment we have Myntra, Zovi, Jabbong, fashion and you, Flipkart, Amazon and Yebhi.com etc. In grocery category the major players include. . We have specialized e-commerce participant like Ferns n Petals, Tilia and Floraindia for flowers and birthday cakes etc.

\section{Changing trends of Retail market \& shopping pattern among people}

The retail industry of India has crossed through numerous periods making new landmarks and the companies have always ready with their modern marketing strategies to align with the landmarks. During the shift from land street side local sales to sophisticated e-retailing via world wide web most of the things have been changed, but the central aspect that did not change is customer satisfaction. All the company makes their strategies to satisfy their customer. Only the way of satisfying 
customer needs to be change with the passing time. The following are the major milestones.

\begin{tabular}{|l|l|}
\hline Period & Shopping Experience \\
\hline During & $\begin{array}{l}\text { During this period limited product options were available in the market. } \\
\text { Shopkeeper had the complete control over the market, products and } \\
\text { customer choice. The selling activities, product offering and after sales } \\
\text { service were accomplished according to the purchasing power and social } \\
\text { status of the customer. }\end{array}$ \\
\hline $\begin{array}{l}\text { During } \\
1980 \text { 's }\end{array}$ & $\begin{array}{l}\text { During this era the products were centralized. Demand factor started } \\
\text { working. Now Producers were dispatching the products as per the } \\
\text { demand of the distribution centres and the shopkeeper had to take these } \\
\text { products as per demand of the customers in a particular areas. The prices } \\
\text { were still controlled by the local shopkeepers. }\end{array}$ \\
\hline $\begin{array}{l}\text { During } \\
1990 \text { 's }\end{array}$ & $\begin{array}{l}\text { This period is known as LPG period. During this period of } \\
\text { Liberalization, Privatisation and Globalization. A large number of } \\
\text { national and international companies were flooded to cover the potential } \\
\text { Indian market. Companies were started spending on advertisement and } \\
\text { providing more and more options at the shopping place to attract the } \\
\text { customers. A type of price war was started. The concept of Customer } \\
\text { care evolved as strategy to compete in the market. Companies had } \\
\text { started use of technology for betterment of market but the optimum use } \\
\text { of it was yet to be made. }\end{array}$ \\
\hline $\begin{array}{l}\text { Dhis is actual technological and customer era. A wide variety of } \\
\text { products and services have flooded in the market by a large number of } \\
\text { companies. Customers are real king of the market. all companies are } \\
\text { ready to provide the products/services with whatever specification they } \\
\text { wish at genuine price and at the desired place. In this era technology } \\
\text { have been using in almost every aspect from production to after sales } \\
\text { service of the product. Now people can book the desired product and } \\
\text { services through various medium like mobile, internet, SMS etc while } \\
\text { sitting at home. Payment options have been upgraded to cash on } \\
\text { delivery, payment via debit card, credit card, cheque, online transfer etc. } \\
\text { Customer can easily know the Delivery time and track their order. He } \\
\text { may also return the product if not found as per expectations. }\end{array}$ \\
\hline Source: Agang
\end{tabular}

Source: Agarwal \& yadav (2014)

\section{OBJECTIVES OF THE STUDY}

The study has been carried out with following objectives:

1. To study the shifting trends in shopping among the consumer.

2. To understand the factors influencing consumer preferences towards online shopping.

3. To suggest suitable strategies for online marketers.

\section{METHODOLOGY}

In order to meet the objectives and to conduct conclusive research, following methodology has been adopted. 


\section{Research Design}

Exploratory as well as descriptive research design has been used for this study.

\section{Nature and source of Data}

This research is based on primary as well as secondary sources of data.

\section{Instruments}

The main instrument for this study was a questionnaire. The questionnaire aimed to gather information about respondentse socio-demographic background, attitude towards online shopping and purchase perception towards online shopping. Therefore, the questionnaire was used to assess knowledge of online purchasing.

\section{Sampling technique and Sample Coverage}

This exploratory research was conducted using 105 sample surveys of respondents who were residing in Gorakhpur city of Uttar Pradesh. A target of 120 people was set, but many respondents did not give complete information so only 105 surveyed questionnaires were considered for data analysis and interpretation. Gorakhpur is a tier 2 city having total population of 4.440,895, out of which 2,277,777 are males and $2,163,118$ are females. Average literacy of Gorakhpur stand at 70.83 but when we see gender wise, male and female literacy were found 81.80 and 59.36 respectively. $81.17 \%$ population constitute the rural segment while only $18.83 \%$ live in the urban areas (as per census 2011).

We have used Non-Probability Sampling Technique namely, convenient sampling for data collection. Data was collected through personal meeting with the students, teachers at the university and college level and some self-employed people. We have also taken the help of social networking sites to fill the questionnaire.

\section{Data collection period}

The data was collected and analysed during Oct 2015-Feb 2016

\section{Data handling and analysis}

The data analysis and processing was done using MS Excel 2010. The percentage analysis, table \& graphs were used for analysing and interpreting the data.

\section{LIMITATIONS OF THE STUDY}

1. The data which we have collected may not fully represent the characteristics of population of interest

2. Those that were willing to fill in questionnaire were included in this survey.

\section{DATA FACTS, ANALYSIS AND INTERPRETATION}

Research instruments, for the purpose of primary data collection were Questionnaires. The questionnaire was divided into 2 parts. First part of the questionnaire contains the socio-demographic and other important information while the second part has the questions related to the factors influencing the choice. 


\section{Demographic profile of respondents}

In this study, demographic variables of the respondents have been considered. It includes the gender, age qualification, income and nature of the family from which the respondents belong.

\begin{tabular}{|l|l|l|l|}
\hline $\begin{array}{l}\text { Demographic } \\
\text { features }\end{array}$ & Particulars & Frequency & Percentage \\
\hline Gender & Male & 73 & $69.52 \%$ \\
\cline { 2 - 4 } & Female & 32 & $30.48 \%$ \\
\hline Age & Age group 18-25 & 18 & 17.142 \\
\cline { 2 - 4 } & Age group 26-35 & 45 & 42.857 \\
\cline { 2 - 4 } & Age group 36-45 & 32 & 30.476 \\
\cline { 2 - 4 } & Above 45 & 10 & 9.523 \\
\hline Education & Primary & 5 & 4.76 \\
\cline { 2 - 4 } & Secondary & 13 & 12.38 \\
\cline { 2 - 4 } & $\begin{array}{l}\text { Graduate/Tech } \\
\text { Diploma }\end{array}$ & 54 & 51.42 \\
\cline { 2 - 4 } & $\begin{array}{l}\text { Masters or above } \\
\text { degree }\end{array}$ & 33 & 31.42 \\
\hline \multirow{5}{*}{ (ncome level } & Up to 15 & 10 & 9.52 \\
\cline { 2 - 4 } & 15-25 & 16 & 15.23 \\
\cline { 2 - 4 } & 25-35 & 33 & 31.42 \\
\cline { 2 - 4 } & 35-45 & 37 & 35.23 \\
\cline { 2 - 4 } & More than 45 & 9 & 8.57 \\
\hline Nature of family & Joint family & 44 & 58.90 \\
\cline { 2 - 4 } & Nuclear family & 61 & \\
\hline
\end{tabular}

\section{Source: field survey}

The profile of the respondents in the study is shown in Table 1 above. Out of total 105 respondents, $69.52 \%$ of the respondents were male and $30.48 \%$ of respondents were female. Less percentage of female shows that the online shopping activity is more deviated towards males. Respondents in the study were categorised into four groups. Majority of respondent (42.85\%) found between the age group of 26-35. This is followed by $30.47 \%$ of respondent who are categorised under age group of 36-45. And finally $9.5 \%$ of respondent were found in the age group of above 45 . The questionnaire responses show that young \& mature person are actively participated in the survey and showing interest in accepting new technology.

It is also observed that most of the people $(51.42 \%)$ were graduate and technically qualified in educational background. $31.42 \%$ respondents were found masters or above degree holder and about $17 \%$ respondent were primary or matriculate. This shows that as the education level increases the people are more likely to believe on new technology and trends.

The majority of the respondents (35.23\%) belonged to the income group of INR 35 to 45 thousand, followed by the respondents $(31.42 \%)$ having income between INR 25 to 35 thousand. $15 \%$ and $9 \%$ of respondents belonged to the income level of 15-25 thousand and less than 15 thousand respectively. Only a few of the respondent (8\%) were found under the income level of above INR 45 thousand. 


\section{ANALYSIS AND INTERPRETATION OF RESULT}

Experience of using Internet

\begin{tabular}{|c|c|c|c|c|}
\hline Particulars & Frequency & Percentage & \multicolumn{2}{|c|}{ Analysis of experience on web } \\
\hline Less than 1 month & 3 & 2.85 & \multirow{4}{*}{$\begin{array}{l}\text { Experience of using internet } \\
3 \%\end{array}$} & \\
\hline Less than 1 year & 15 & 14.28 & & Less than 1 \\
\hline 1-2 Years & 17 & 16.19 & & $\begin{array}{l}\text { Less than } 1 \\
\text { year }\end{array}$ \\
\hline 3-4 Years & 41 & 39.04 & & $1-2$ Years \\
\hline More than 5 year & 29 & 27.61 & & $\begin{array}{l}\text { 3-4 Years } \\
\text { More than } \\
5 \text { year }\end{array}$ \\
\hline
\end{tabular}

The data shows that maximum people had an experience of 3-4 years, followed by group of people having more than 5 year experience. 17 people had an experience of 1-2 year, 15 people were interviewed having less than 1 year experience. Only 3 people surveyed were an experience of less than 1 month. 


\section{Internet shopping frequency}

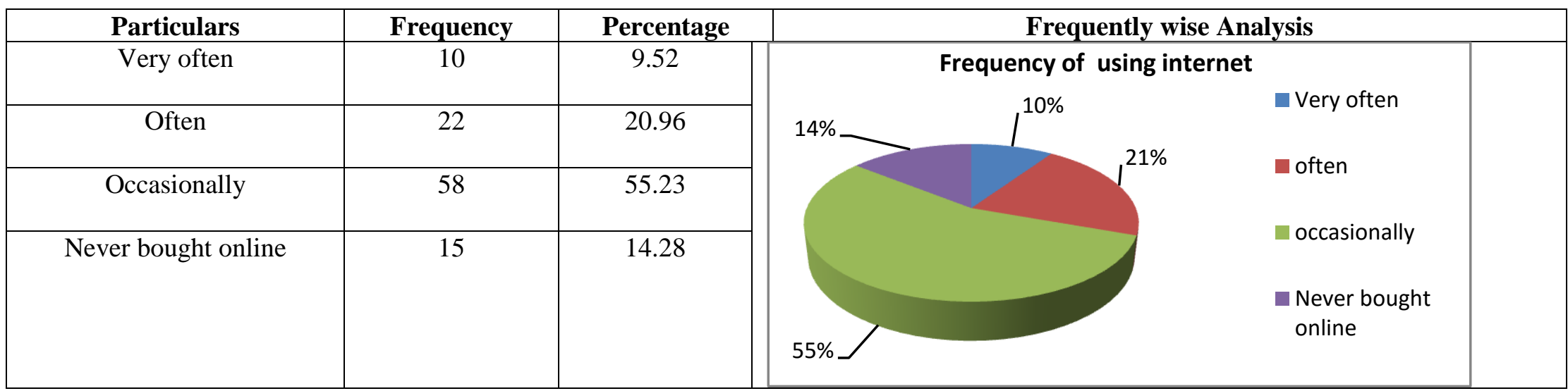

From the above table and figure we can see that maximum numbers of the internet users in Gorakhpur occasionally shop online. More than $20 \%$ of people are those who often buy the product \& services through online medium. Only $9 \%$ are those who use online shopping website for purchasing different products very frequently. This indicates that people of Gorakhpur are not addicted of shopping online, probably they use internet for other purposes. 
Frequency of online shopping during last one year

\begin{tabular}{|c|c|c|c|c|}
\hline Particulars & Frequency & Percentage & \multicolumn{2}{|c|}{ Purchase Analysis of last one year } \\
\hline More than 3 times & 16 & 17.77 & & \multicolumn{2}{|c|}{ Frequency of online shopping in last one } \\
year & & \\
\hline $1-3$ times & 19 & 21.11 & \\
\hline At least once & 51 & 56.66 & \\
\hline Nil & 4 & 4.44 & \\
\hline
\end{tabular}

The above Table and Figure shows purchasing frequency of people which depict that majority of the respondents (57 percent) purchased product or services online at least once time in the past one year. 21 percent of respondents bought online things 1-3 times, and 18 percent respondents purchased more than 3 times in last one year. Only 4 percent of respondent did not purchased anything from online website in last one year. The data indicates that the people of Gorakhpur distt are not habituated for e-shopping but recently involved in it.

\section{Interest in online shopping festivals \& events}

\begin{tabular}{|c|c|c|c|}
\hline Particulars & Frequency & Percentage & \multicolumn{2}{c|}{ Analysis of preference about festival offer } \\
\hline $\begin{array}{c}\text { Yes, it gives more discount } \\
\text { then regular given offers }\end{array}$ & 69 & 76.66 & \multirow{2}{*}{$\begin{array}{c}\text { Interest in online shopping festivals \& } \\
\text { events }\end{array}$} \\
\cline { 1 - 2 } No, don't bother about it & 21 & 23.33 & \\
Yes, it gives \\
more offers
\end{tabular}


From the above table and figure it can be said that during online shopping festivals \& events people are more tend to browse and purchase product and services online, as most of the respondents $(77 \%)$ replied that they generally wait for these type of online shopping festivals. Only 23 per cent respondent said that they don't think about the same and purchase things as usual in normal manner.

\section{Expenditure on an average during online purchase}

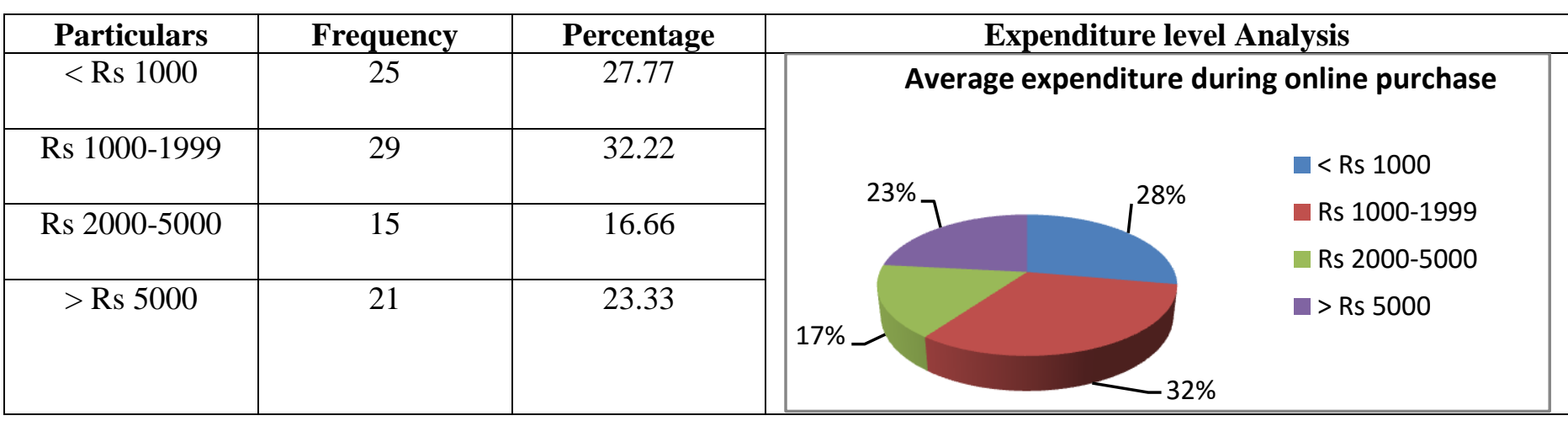

In terms of money spent, we can conclude from the above table \& graph that 23 percent of respondent spend more than Rs 5000 average during online purchasing.17 percent and 32 percent of respondent expedite between the range of Rs 2000-5000 and Rs 1000-1999 respectively.28 percent of the respondent use less than Rs 1000 during e-shopping.

\section{Most frequently purchased item}

\begin{tabular}{|c|c|c|c|}
\hline \multirow[t]{2}{*}{ S.no } & \multirow[t]{2}{*}{ Items } & \multicolumn{2}{|c|}{ Respondents } \\
\hline & & No. & $\%$ \\
\hline 1 & Tickets/ travelling services /hotel* & 57 & 63.33 \\
\hline 2 & Banking \& other financial services* & 11 & 12.22 \\
\hline 3 & Books/magazine $*$ & 23 & 25.55 \\
\hline 4 & Software/CD/DVD* & 36 & 40.00 \\
\hline 5 & Apparel \& accessories* & 69 & 76.66 \\
\hline 6 & Consumer Electronic/mobile phones* & 71 & 78.88 \\
\hline 7 & Personal care products* & 42 & 46.66 \\
\hline 8 & Others* & 16 & 17.77 \\
\hline
\end{tabular}

$*=$ multi response 


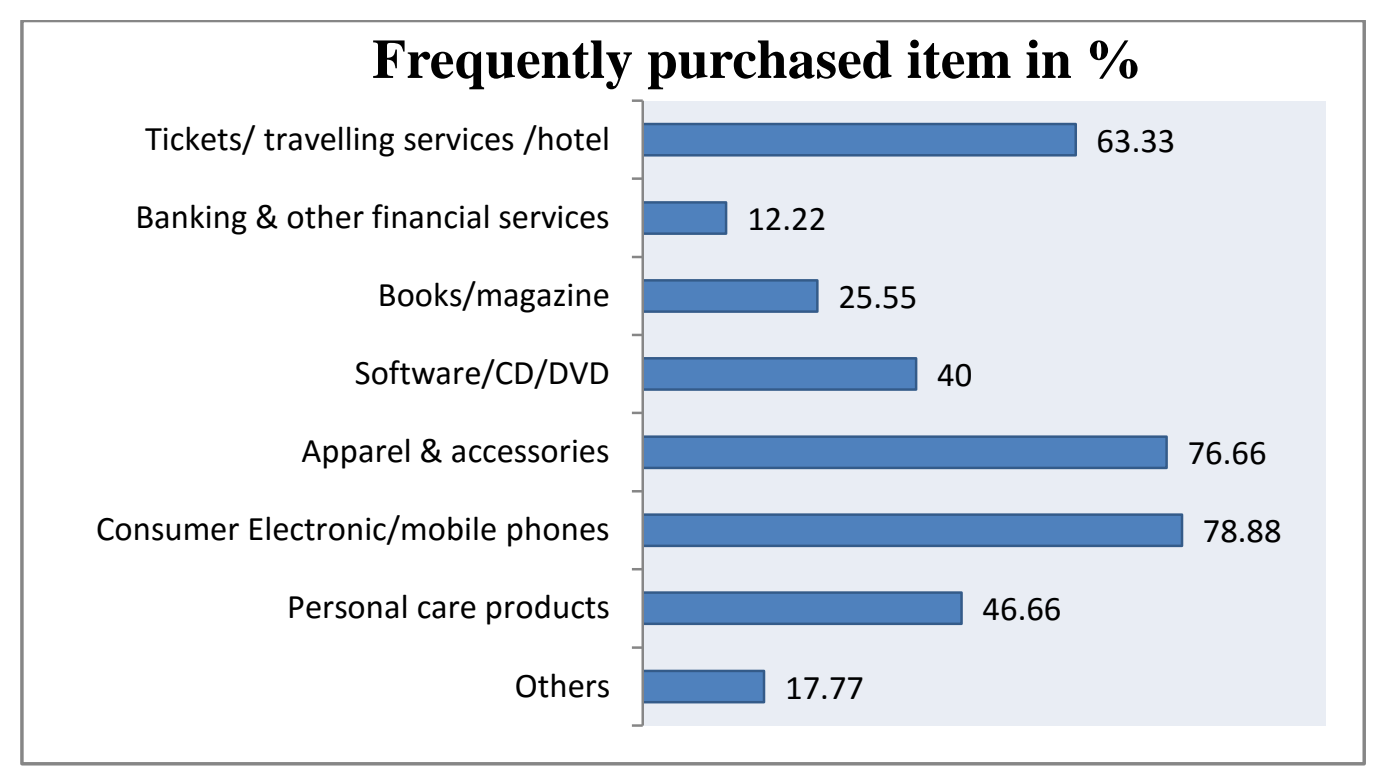

From the above chart and table, from the large variety of goods and services on offer on online website, the survey reveals that consumer electronics, mobile etc. formed the major portion $(78.88 \%$ ) of online purchases, followed by apparel \& accessories $(76.66) .63 .33 \%$ of the respondents agreed that they purchase travelling ticket, hotel booking though online websites. About $46.66 \%$ of respondents replied that they prefer to purchase personal care products (cosmetics, perfumes make up kit etc.) from online websites. This is followed by software, CD, DVD purchase (40\%). Books \& magazines were bought by 25.55 percent of the respondents. 12.22 percent respondents involved in purchasing of banking \& other financial services. 
Payment mode generally preferred by respondents

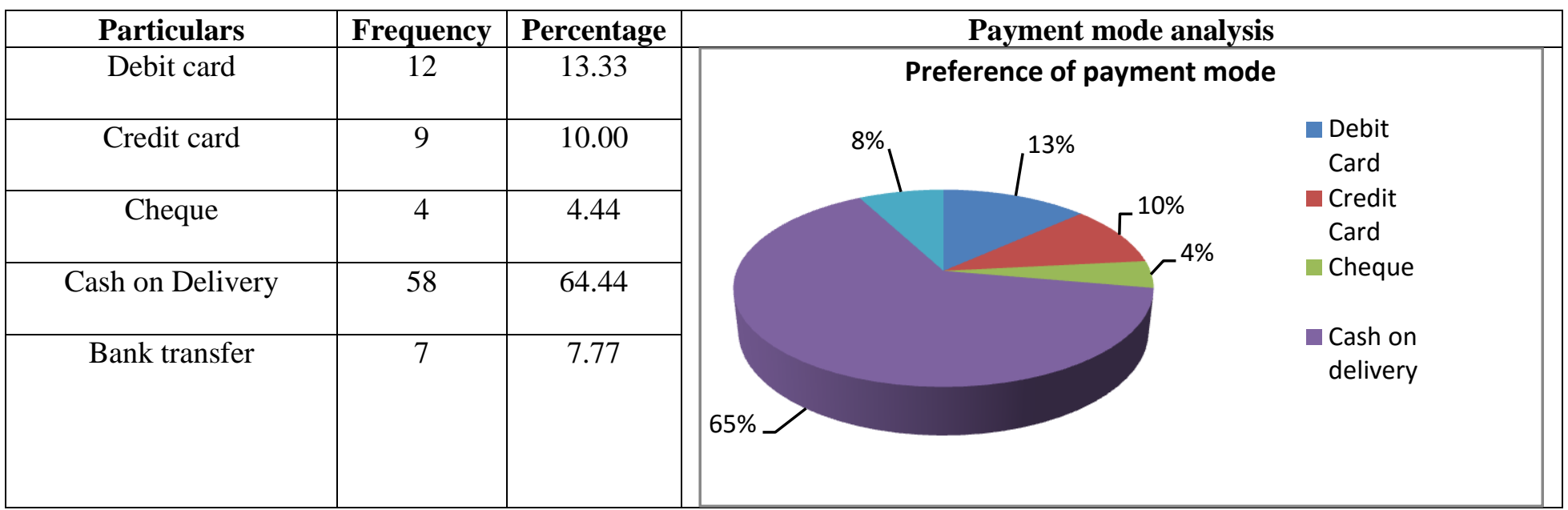

From the above table and figure it is clearly identified that most of the customer (more than 64\%) like to choose cash on delivery option for the payment of the order. Payment through debit card is the second most favourable option to purchase as due to spreading of financial inclusion almost every people is opening at least a bank account along with debit card. Thus we can conclude that customers don't want to face any type of tension (payment failure but deduction, charge of using internet and payment card service charge etc.) 


\section{Experiences of respondents with buying on internet}

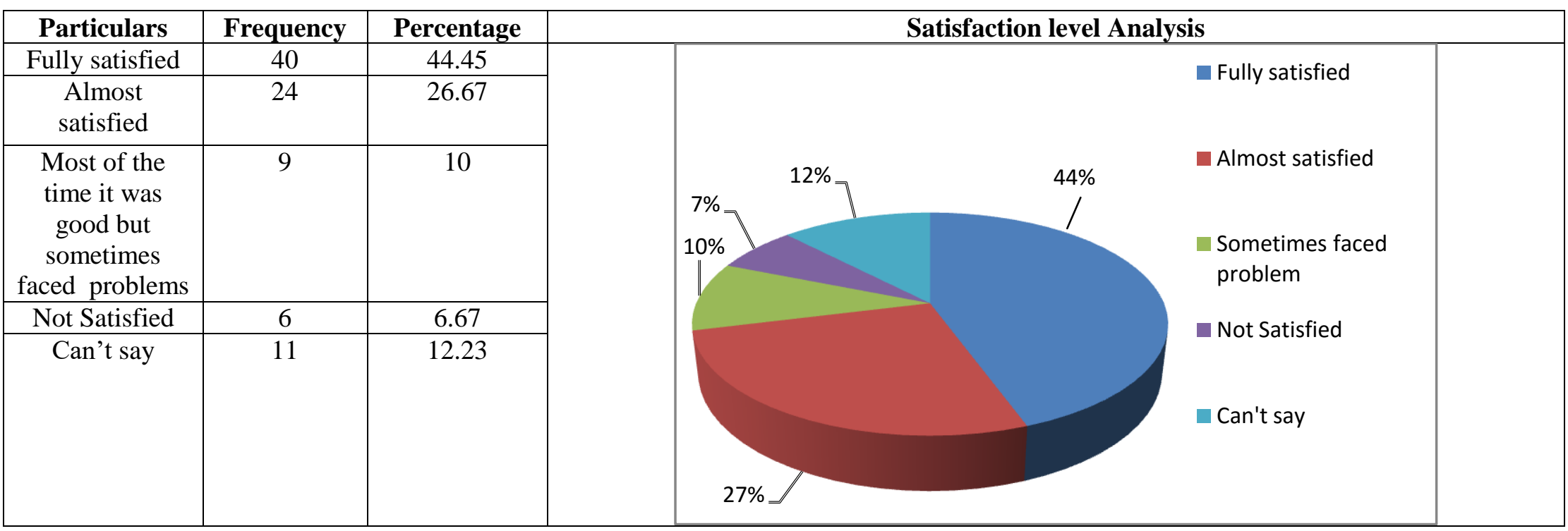

Through above data it is clearly visible that most of the people like and enjoy the shopping through digital medium. More than 70 percent of respondent gave their positive response as either fully or almost satisfied from online shopping. Thus there is great opportunity in sector.

\section{Why the consumer preferences are changing?}

A great percentage of population of the world are accessing internet and performing financial transaction over the web (McQuitty and Peterrson, 2000; Xing et al., 2004; Keen et al., 2002).This ultimately growing the conduct of business via electronic means (joines et al., 2003) and all of the firms and organisation are competing to avail this business opportunities on the web (Hoffman, 2000 ;Liao \& Cheung, 2001). Dittmar et. al (2004) added that purchase thorough online transaction is a remote process and the consumer does not feel like actually spending money, so many consumer involves in overspending. This appears a very positive point for e-retailers and they try to motivate the customers 
Online shopping or e-shopping is a form of electronic commerce through which consumers can directly buy product \& services from seller over the internet using a web browser (wikepedia). While e-market can be seen as an inter-organisational system that that permit the buyers and sellers to exchange needed information about prices and product offerings (Bakos., 1991).

There are several factors which have contributed to increase the use of electronic means by consumers to shop online. These are:

- Increase in education level (Burke, 2002)

- Increment in household income (Lohse et al., 2000; Lu et al.,2003; Hubona and Kennick, 1996)

- changes in lifestyles (Donthu and Garcia ,1999)

- Time-deprivation and multi-tasking are graduating consumers to an attachment towards online shopping and being reliant on it (Assael, 2005; Ernst and Young 2012). In the present era, nuclear families are increasing and both husband and wife are working, as they have less time to go to the market for purchasing commodities.

- Usefulness for the customer (Monsuwé et al., 2004)

- Easy and wide access to products, services and information, leading to overall convenience [Rohm and Swaminathan, 2004; Bhatnagar et al., 2000; Grewal et al., 2002], avoidance of crowds, and 24 hour shopping availability (Karayanni, 2003)

- Large number of variety (Szymanski and Hise, 2000)

- Situational factors (Avery, 1996;Wolfinbarger and Gilly, 2001)

- Problem solving for customer (Babin et al., 1994)

- Enjoyment on the part of the customer (Babin et al., 1994 ;Hirschman, 1983; Childers et al., 2001; Menon and Kahn, 2002)

- Demographic and personality traits of consumers (Eastlick and Lotz, 1999; Burke, 2002; Swinyard and Smith 2003;Dabholkar and Bagozzi, 2002;; Wu, 2003)

- Previous online shopping experiences (Eastlick and Lotz, 1999; Shim et al., 2001;Weber and Roehl, 1999)

- The number of people in India who use the Internet has grown 6,900\% since the year 2000 (Internet World Stats 2015). Overall internet user base of India is expected to reach 402 million (with $49 \%$ growth over last year) by December 2015 and 426 million by June 2016(Joint report of IAMAI and IMRB International; Vijaya kumar. S , 2015). There is a positive relationship between Internet usage and online shopping intention (Bhatnagar et al. 2000; Citrin et al. 2000; Liao and Cheung 2001; Park 2002)

\section{Main barriers of online shopping}

\begin{tabular}{|c|c|c|}
\hline $\begin{array}{l}\text { Main barriers for not shopping } \\
\text { online }\end{array}$ & Frequency & Percentage \\
\hline Fear about payment security & 53 & 50.48 \\
\hline $\begin{array}{c}\text { Don't want to disclose personal } \\
\text { information }\end{array}$ & 11 & 10.48 \\
\hline $\begin{array}{c}\text { Physical checking \& interaction is } \\
\text { not possible }\end{array}$ & 17 & 16.19 \\
\hline Complex process & 10 & 9.52 \\
\hline
\end{tabular}




\begin{tabular}{|c|c|c|}
\hline $\begin{array}{c}\text { Low or absence of customer } \\
\text { support }\end{array}$ & 3 & 2.85 \\
\hline $\begin{array}{c}\text { Can't wait, immediate possession } \\
\text { is not possible }\end{array}$ & 9 & 8.57 \\
\hline High shipping cost & 2 & 1.90 \\
\hline
\end{tabular}

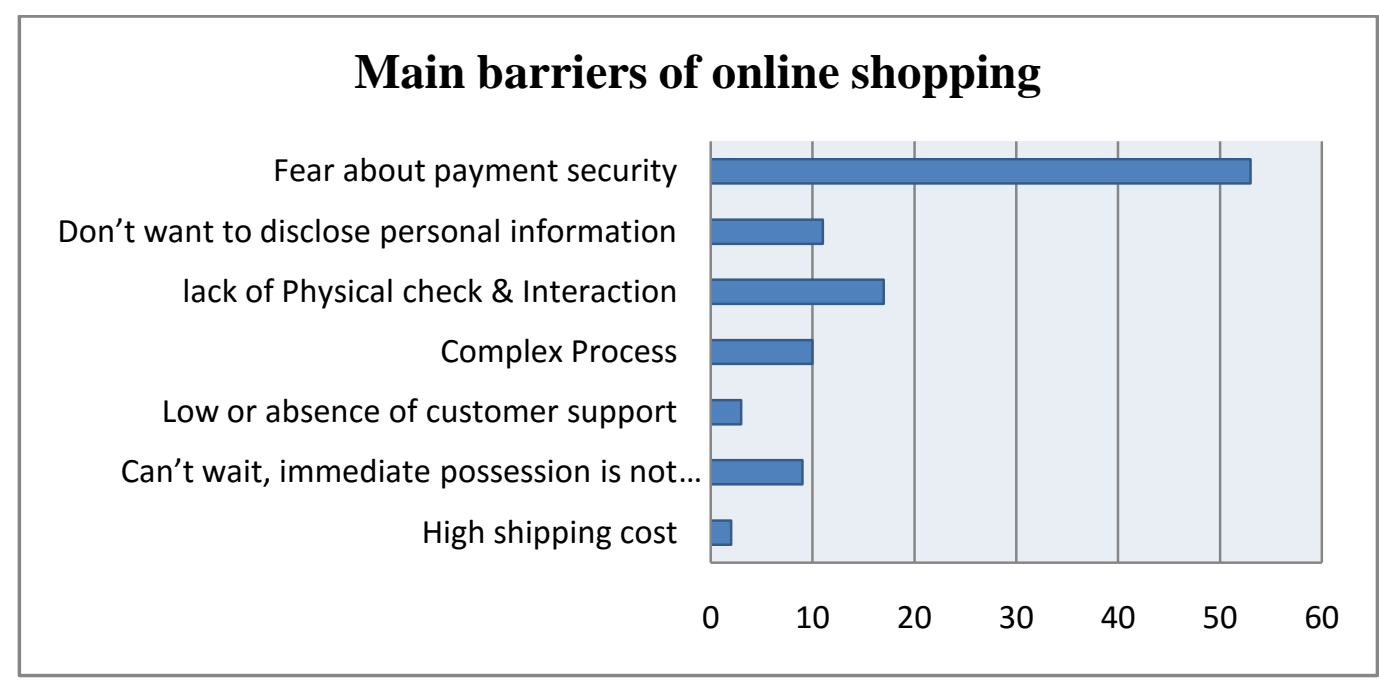

This barrier related question was asked to the entire 105 respondent who actually filled the questionnaire. The result revealed that more than 50 per cent of respondent given their consent about fear of payment safety. 10 per cent of respondent replied that they don't want to disclose their personal information as they suspect that the information like name, address, phone number, bank $\mathrm{A} / \mathrm{c}$ and payment card detail etc may be given or sold to other companies or persons (kim et al., 2008). The consumer worries about risk, security and privacy (Bhatnagar et al., 2000; Liebermann and Stashevsky, 2002; Kargaonkar and Wolin, 1999). About 16 per cent respondent agreed upon the reason of absence of physical check and interactivity in online shopping. The researchers (La and Kandampully, 2002; Wee and Ramachandra, 2000) agreed that lack of physical presence and interactivity affects the willingness to purchase through e-shop.10 per cent of respondent replied that technical complexity of online transaction, return process, warranty policy are the important barrier for not shopping online. Seiders et al., (2000) aligned with our research for technical complexity. More than 8 per cent respondent said that lack of immediate possession is the reason behind of not shopping online.

\section{SUGGESTION \& CONCLUSION}

The techno-communicational oriented e-retail is growing rapidly and there has been found a transformational shift from traditional store setup to more sophisticated virtual stores. Although the number of persons purchasing goods \& services continue to rise in India, but it has been found that some e-retailers are enjoying more success and some are struggling for survival. This creates a need for analysis from the consumers' perspective that what are the factors that attract retain and satisfy them. In Gorakhpur which is the tier II city of India, the online experiences still viewed as the complex and uncomfortable. In this type of situation the e-retailers would have to develop \& utilize those marketing practices which are based on the comprehensive consumer behavioural research. To grow in this competitive environment the e- 
retailer would have to understand the customer needs and endeavour to cultivate the feelings of security and trust among the e-shoppers. Transparent business terms, conditions, warranty and return policies, and special focus on data privacy and security, implementing safe $\&$ advanced technology will definitely increase the sense of trust and safety on those e-retailers. The e- shopping portal should be designed as user friendly \& simple with relevant and clear cut information about product/services, price, features, and delivery schedule, thus decreasing the conservative mental blockage with respect to computer use and online purchase. Quick and effective after sale and 24 hrs customer support will reduce the dissatisfaction if any. Some online retailers are using the scheme of money back guarantee that they will return all money if the customer not get satisfaction with the product/service. This type of trial purchase is a good scheme which may secure a repeat purchase if customer is satisfied.

\section{References}

1. Agarwal.A., \& Yadav,V.K.(2014). Impact of Technology in E-Retailing Operations: A Consumer Perspective. In Proceedings of $18^{\text {th }}$ Annual International Conference of the Society of Operations Management (SOM14)

2. Assael, H.,2005.A demographic and psychographic profile of heavy Internet users and users by type of internet usage .J.Advert.Res.45(1),93-123.

3. Avery, R.J. (1996), "Determinants of search for non-durable goods: an empirical assessment of the economics of information theory", The Journal of Consumer Affairs, Vol. 30 No. 2, pp. 390-406.

4. Babin, B.J., Darden, W.R. and Griffin, M. (1994), "Work and/or fun: measuring hedonic and utilitarian shopping value", Journal of Consumer Research, Vol. 20, pp. 644-56.

5. Bakos, J.Y. 1991. A strategic analysis of electronic marketplaces, MIS Quarterly 15(3), 295-310.

6. Bhatnagar, A., Misra, S. and Rao, H. R.(2000), "on Risk, Convenience, and Internet Shopping Behaviour," Communications of the ACM Vol. 43, No. 11: 98-105..

7. Burke, R.R. (2002), "Technology and the customer interface: what consumers want in the physical and virtual store", Journal of the Academy of Marketing Science, Vol. 30 No. 4, pp. 411-32.

8. Childers, T.; Carr, C.; Peck, J.; and Carson, S. 2001. Hedonic and utilitarian motivations for online retail shopping behavior, Journal of Retailing 77(4), 511-38.

9. Citrin, A. V., Sprott, D. E., Silverman, S. N. and Stem Jr, D. E.,(2000) "Adoption of Internet Shopping: the Role of Consumer Innovativeness," Industrial Management \& Data Systems Vol. 100, No. 7: 294-301.

10. Dabholkar, P.A., and Bagozzi, R.P. 2002. An attitudinal model of technology-based self-service: Moderating effects of consumer traits and situational factors, Journal of the Academy Marketing Science 30(3), 184201.

11. Dittmar H., Long K., and Meek R.(2004). Buying on the Internet: Gender Differences In Online and Conventional Buying Motivations. Sex Roles, 50 (5-6), 423-44.

12. Donthu, N.,Garcia,A.,1999.Theinternetshopper.J.Adv.Res.39(3),52-58.

13. Ernst \&Young,2012.There-birthofe-commerceinIndia.Availableat: 〈http:// ww.ey.com/Publication/vwLUAssets/Rebirth_of_e-

Commerce_in_India/\$FILE/ EY_RE-BIRTH_OF_ECOMMERCE.pdf $\rangle$ 
14. Eastlick, M.A. and Lotz, S.L. (1999), "Profiling potential adopters of an interactive shopping medium", International Journal of Retail and Distribution Management, Vol. 27 No. 6/7, pp. 209-23.

15. Grewal, D., Iyer, G.R. and Levy, M. (2002), "Internet retailing: enablers, limiters and market consequences", Journal of Business Research.

16. Hirschman, E.C. 1983. Predictors of self-projection, fantasy fulfilment, and escapism, Journal of Social Psychology 120, 63-76.

17. Hoffman, D. 2000. The revolution will not be televised, Introduction to the special issue on marketing science and the internet, Marketing Science 19(1), 1-3.

18. Hubona, G.S. and Kennick, E. (1996), "The impact of external variables on information technology usage behavior", IEEE Proceedings of the Hawaii International Conference on System Sciences, Vol. 4, IEEE Press, Los Alamitos, CA, pp. 166-75.

19. Joines, J.L.; Scherer, C.W.; and Scheufele, D.A. 2003. Exploring motivations for consumer web use and their implications for E-Commerce, Journal of Consumer Marketing 20(2), 90-108.

20. Karayanni, D. A. (2003). Web-shoppers and non-shoppers: Compatibility, relative advantage and demographics.European Business Review, 15(3), 141152.

21. Korgaonkar, P.K., and Wolin, L.D. 1999. A multivariate analysis of web usage, Journal of Advertising Research 39(2), 53-68.

22. Keen, C.; Wetzels, M.; de Ruyter, K.; and Feinberg, R. 2002. E-tailers versus retailers: Which factors determine consumer preferences?, Working Paper 2001-02, Maxx Working Paper Series.

23. Kim, D. J., Ferrin, D. L., \& Rao, H. R. (2008). A trust-based consumer decision-making model in electronic commerce: the role of trust, perceived risk, and their antecedents. Decision Support Systems, 44(2), 544e564.

24. La, V.K., and Kandampully, J. 2002. Electronic retailing and distribution of services: Cyber intermediaries that serve customers and service providers, Managing Service Quality 12(2), 100-16.

25. Liao, Z. and Cheung, M. T.,(2001) "Internet-Based E-Shopping and Consumer Attitudes an Empirical Study," Information \& Management Vol. 38, No. 5: 299-306.

26. Liebermann, Y., and Stashevsky, S. 2002. Perceived risks as barriers to Internet and E-commerce usage, Qualitative Market Research: An International Journal 5(4), 291-300.

27. Lohse, G.L., Bellman, S. and Johnson, E.J. (2000), "Consumer buying behaviour on the internet: findings from panel data", Journal of Interactive Marketing, Vol. 14 No. 1, pp. 15-29.

28. Lu, J., Yu, C.S., Liu, C. and Yao, J. (2003), “Technology acceptance model for wireless internet", Internet Research: Electronic Networking Applications and Policy, Vol. 13 No. 3, pp. 206-22.

29. McQuitty, S., and Peterson, R.T. 2000. Selling home entertainment on the internet: an overview of a dynamic marketplace, Journal of Consumer Marketing 17(3), 233-48.

30. Menon, S., and Kahn, B. 2002. Cross-category effects of induced arousal and pleasure on the Internet shopping experience, Journal of Retailing 78(1), 3140.

31. Monsuwé, T; Dellaert, B.; and Ruyter, K. 2004. What drives consumers to shop online? A literature review, International Journal of Service Industry Management 15(1), 102-21. 
32. Park, C., "A Model on the Online Buying Intention with Consumer Characteristics and Product Type." Proceedings of Ausweb, The Eighth Australian World Wide Web Conference, Queensland, Australia, 2002.

33. Rohm, A., and Swaminathan, V. 2004. A typology of online shoppers based on shopping motivations, Journal of Business Research 57, 748-57.

34. Seiders, K.; Berry, L.L.; and Gresham, L.G. 2000. Attention, retailers! How convenient is your convenience strategy? Sloan Management Review 41(3), 79-89.

35. Shim, S.; Eastlick, M.A.; Lotz, S.L.; and Warrington, P. 2001. An online prepurchase intentions model: The role of intention to search, Journal of Retailing 77, 397-416.

36. Swinyard, W., and Smith, S. 2003. Why people (don't) shop online: A lifestyle study of the Internet consumer, Psychology \& Marketing 20(7), 56797.

37. Szymanski, D.M.,Hise, R.T.,2000.E-satisfaction:an initial examination. Journal of Retailing 76(3), 309-322.

38. Weber, K., and Roehl, W.S. 1999. Profiling people searching for and purchasing travel products on the worldwide web, Journal of Travel Research 37, 291-98.

39. Wee, K.N.L., and Ramachandra, R. 2000. Cyber buying in China, Hong Kong and Singapore: Tracking the who, where, why and what of online buying, International Journal of Retail \& Distribution Management 28(7), $307-16$.

40. Wolfinbarger, M., and Gilly, M.C. 2001. Shopping online for freedom, control, and fun, California Management Review 43(2), 34-55.

41. $\mathrm{Wu}, \mathrm{S}$. 2003. The relationship between consumer characteristics and attitude toward online shopping, Marketing Intelligence \& Planning 21 (1), 37-44.

42. Xing, X.; Tang, F.; and Yang, Z. 2004. Pricing dynamics in the online consumer electronics market, Journal of Product \& Brand Management 13(6), 429-41.

43. Vijayakumar .S (2015),India's Internet user base to touch $402 \mathrm{mn}$ by December, surpassing U.S.

44. http://www.thehindu.com/business/Industry/indias-internet-user-base-totouch-402-mn-by-december-surpassing-us/ article7888744.ece 